\title{
Prediction of Human Performance Time to Find Objects on Multi-display Monitors using ACT-R Cognitive Architecture
}

\author{
Hyungseok Oh ${ }^{1}$, Rohae Myung ${ }^{1}$, Sang-Hyeob Kim ${ }^{2}$, Eun-Hye Jang ${ }^{2}$, Byoung-Jun Park ${ }^{2}$ \\ ${ }^{1}$ School of Industrial Management Engineering, Korea University, Seoul, 136-713 \\ ${ }^{2}$ BT Convergence Technology Research Department, Electronics and \\ Telecommunications Research Institude, Daejeon, 305-700
}

\begin{abstract}
Objective: The aim of this study was to predict human performance time in finding objects on multi-display monitors using ACT-R cognitive architecture. Background: Display monitors are one of the representative interfaces for interaction between people and the system. Nowadays, the use of multi-display monitors is increasing so that it is necessary to research about the interaction between users and the system on multi-display monitors. Method: A cognitive model using ACT-R cognitive architecture was developed for the model-based evaluation on multi-display monitors. To develop the cognitive model, first, an experiment was performed to extract the latency about the where system of ACT-R. Then, a menu selection experiment was performed to develop a human performance model to find objects on multi-display monitors. The validation of the cognitive model was also carried out between the developed ACT-R model and empirical data. Results: As a result, no significant difference on performance time was found between the model and empirical data. Conclusion: The ACT-R cognitive architecture could be extended to model human behavior in the search of objects on multi-display monitors. Application: This model can help predicting performance time for the model-based usability evaluation in the area of multi-display work environments.
\end{abstract}

Keywords: ACT-R, Cognitive architecture, Model-based evaluation, Multi-display monitors

\section{Introduction}

\subsection{Overview}

Human-Computer Interaction(HCI) 분야에서는 시스템 을 설계하는 데 있어서 인간이 시스템과 어떻게 상호작용하 는지에 대해 고려하는 것은 매우 중요하다고 알려져 왔다. 이에 인간이 시스템과 상호작용하기 위해 필요한 인터페이 스에 대한 연구가 매우 중요하다. 이러한 인터페이스 중 대
표적인 것이 바로 디스플레이 인터페이스로서 디스플레이 인터페이스는 다중 융합 환경에서 인간과 커뮤니케이션 할 수 있는 하나의 방법이라 할 수 있다(Chung, 2011). 특히, 디스플레이 인터페이스에 있어서의 다중 모니터는 최근 점 점 더 큰 작업 영역이 필요해짐에 따라 여러 연구기관, 증권 사와 같은 사무실, 제어, 관리실 등뿐만 아니라 실생활 전반 에까지 확대되고 있다. 이에 이러한 다중 모니터를 이용하 여 사람이 어떻게 시스템과 상호작용하는지에 대해서 분석 하는 것이 필요하다. 특히, 다중 모니터는 사람이 처리해야

Corresponding Author: Rohae Myung. School of Industrial Management Engineering, Korea University, Seoul, 136-713.

Mobile: +82-10-8915-3392, E-mail: rmyung@korea.ac.kr

Copyright@2013 by Ergonomics Society of Korea(pISSN:1229-1684 eISSN:2093-8462). All right reserved.

(c) This is an open-access article distributed under the terms of the Creative Commons Attribution Non-Commercial License(http://creativecommons.org/licenses/by-nc/3.0/), which permits unrestricted non-commercial use, distribution, and reproduction in any medium, provided the original work is properly cited. http://www.esk.or.kr 
할 작업 영역이 넓을 때 사용되기 때문에 이러한 넓은 작업 영역에서 사람이 어떻게 행동하는 지에 대한 연구가 필요 하다. 또한, Sanders \& McCormick (1993)과 US military standards(US DoD, 1981) 등의 visual angle의 연구에서 도 사람들은 수평적으로 $\pm 15^{\circ}$ 정도의 visual angle을 선호 하기 때문에 이를 벗어나는 넓은 작업 영역에서의 대상을 찾 는 사람의 행동은 좁은 영역에서와는 충분히 다를 수 있다. 이에 본 연구에서는 넓은 작업 영역, 특히, 넓은 작업 영역의 대표적인 인터페이스 환경인 다중 모니터 환경에서의 원하 는 대상을 찾는 사람의 행동을 어떻게 예측할 수 있는 지에 대해서 알아보았다.

한편, $\mathrm{HCI}$ 분야에서는 새로운 시스템을 개발할 경우에 사용성 평가를 통해 시스템의 인터페이스가 효율적인지를 평가하게 되는데, 이러한 사용성 평가는 시스템의 개발 단계 에서 피실험자를 선발, 훈련시켜 시제품을 통해 반복적인 평 가를 통해서 이루어진다. 하지만, 이러한 방식은 시간과 비 용이 많이 소요되어 시스템의 개발 주기가 매우 짧아지고 있는 최근 상황에 있어서 적합하지 않다. 이에, 최근에는 이 러한 문제점을 보완하기 위해 피실험자를 선발하고 훈련시 키는 과정을 거치지 않고 정량적인 평가가 가능한 Modelbased Evaluation을 이용하여 사용성 평가가 이루어지고 있다.

이러한 Model-based Evaluation은 ACT-R (Byrne \& Anderson., 1997; Byrne, 2001; Anderson et al., 2004), SOAR (Laird et al., 1983), EPIC (Kieras \& Meyer, 1997) 과 같은 인지아키텍처(Cognitive Architecture)를 이용하 여 사람의 실제 인지 과정을 묘사해 주는 인지 모델을 작성 하거나 GOMS (Card et al., 1983; John \& Kieras, 1996a, $1996 \mathrm{~b})$ 와 같은 모델을 이용하여 사람의 행동을 정량적으로 예측할 수 있게 해주는 방법이다. 특히, $\mathrm{ACT}-\mathrm{R}$ 은 사람의 행동을 학습(Anderson \& Matessa, 1998), 운전(Salvucci, 2006) 등과 같은 높은 수준의 인지 과정에서부터 메뉴 선 택 (Min et al., 2010; Lim et al., 2012; St. Amant et al., 2007) 과 같은 낮은 수준의 인지 과정까지 milliseconds 단 위로 세부적으로 표현해 줄 수 있어 여러 분야에서 널리 사 용되고 있다. 이에, 본 연구에서는 이러한 $\mathrm{ACT}-\mathrm{R}$ 인지아 키텍처를 사용하여 넓은 작업 영역에서 원하는 대상을 찾는 사람의 행동을 예측하기 위한 인지 모델을 작성하였다.

\subsection{Visual processing of ACT-R}

Goodale \& Milner(1992)에 의하면, 사람이 눈을 이용하 여 대상을 인식하는 시각처리 과정은 2가지 흐름으로 이루 어져 있다고 한다. 이는, 사람이 시각처리 과정을 수행하는 데 있어서 시각과 관련된 대뇌 피질에서 이루어지는 과정을
나타내는 것으로써, 먼저 Dorsal Stream에서 찾고자 하는 대상의 위치가 어디 있는지 파악하여 눈을 그 위치에 움직인 다. 그 다음, Ventral Stream에서 찾고자 했던 대상에 대해 Recognition을 수행하게 된다. $\mathrm{ACT}-\mathrm{R}$ 은 이러한 사람의 시 각 처리에 있어서 2가지 흐름을 그대로 반영하여 Dorsal Stream과 관련된 과정을 Where System으로, Ventral Stream과 관련된 과정을 What System으로 설명하였다. 이에 ACT-R에서는 사람의 시각 처리를 Where System 에서 확인하고자 하는 대상의 위치를 먼저 찾은 후, What System에서 그 위치로 주의를 이동시켜서 대상을 확인할 수 있도록 하여 사람의 시각 처리를 표현하고 있다(Byrne \& Anderson, 1998). 여기서 각 System에서의 Latency는 What System에서 주의를 이동시키는 데 $185 \mathrm{~ms}$ 가 소요되 며, Where System에서는 따로 시간이 소요되지 않는다. 하 지만, 이는 하나의 모니터를 사용하는 환경에 있어서 추출된 값으로 다중 모니터와 같은 넓은 범위의 환경에서는 Where System 역시 대상의 위치에 따라 다른 Latency 값이 적용 될 수 있다.

이에, 본 연구에서는 더 정확한 인지 모델을 작성하기 위 해 실험을 수행하여 Where System에 대한 Latency 값을 추출한 다음 다중 모니터 환경에서 대상을 찾는 사람의 행동 을 예측하기 위한 인지 모델을 작성하였다.

\section{Method}

앞서 언급한 바와 같이 본 연구에서는 다중 모니터 환경에 서 대상을 찾는 것과 관련되어 2가지 실험을 통해서 Where System에서의 Latency 값을 추출하여 인지 모델을 작성하 고 이를 다중 모니터 환경에서의 메뉴 선택과 관련된 과제를 수행하는 인지 모델을 작성하고 이를 실험을 통해서 검증하 였다.

\subsection{Experiment $1 \& 2$}

\subsubsection{Participants \& apparatus}

모든 실험은 현재 다중 모니터를 사용하고 있는 나이가 20대인 대학생/대학원생 8명을 피실험자로 구성하여 실험을 진행하였다.

실험에서 사용된 모니터는 22 인치 (해상도: $1,680 \times 1,050$ ) 와 17 인치 모니터(해상도: $1,280 \times 1,024$ ) 2 개를 사용하였 다. 모니터들의 배치는 Figure 1 과 같이 22 인치 모니터 양 옆으로 17 인치 모니터를 $135^{\circ}$ 만큼 기울여서 두었다. 또한, 피실험자는 가운데 모니터에 $50 \mathrm{~cm}$ 떨어진 위치에서 실험을 
수행하도록 하였다.

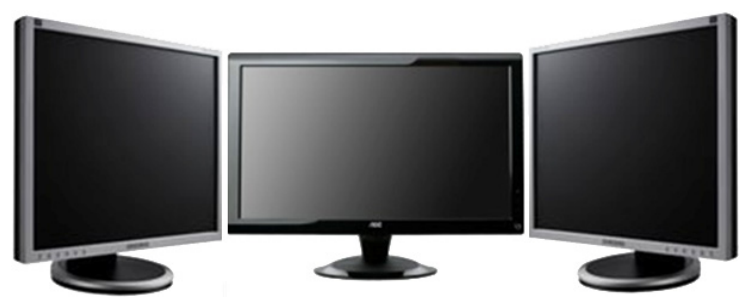

Figure 1. Experimental multi-display monitors

\subsubsection{Procedures}

$\mathrm{ACT}-\mathrm{R}$ 의 Where System의 Latency 값을 추출하기 위 해 2가지 실험을 수행하였다.

첫 번째 실험은 Figure 1 과 같은 다중 모니터 환경에서 피실험자가 예측하지 못하는 위치에 나타나는 대상을 찾는 것으로써, 실험 절차는 아래와 같다.

1. 실험이 시작하면, 가운데 모니터의 한가운데에 "X"자 가 나타난다. 피실험자는 이 "X"자를 응시한다.

2. 3초 후에 "X"자 위치에 "START"라는 글자가 나타나 는 동시에 "X" 위치로부터 Figure 2 와 같이 $20^{\circ}, 30^{\circ}$, $40^{\circ}, 50^{\circ}, 60^{\circ}$ 중에 임의의 하나의 각만큼 오른쪽이나 왼쪽 방향으로 떨어져서 1 3 사이의 숫자가 나타난다. 피실험자는 "START"라는 글자를 확인한 뒤, 함께 나 타나는 1 3의 숫자가 있는 위치로 시선을 이동한다.

3. 나타난 숫자에 해당하는 값을 키보드에 입력한다. 이 때, "START"가 나타날 때부터 값을 입력할 때까지의 시간이 저장된다.

4. 각 각도마다 왼쪽 5 번, 오른쪽 5 번 반복하여 수행한다. 또한, 오류가 발생하였을 경우 다시 수행하도록 하였다.

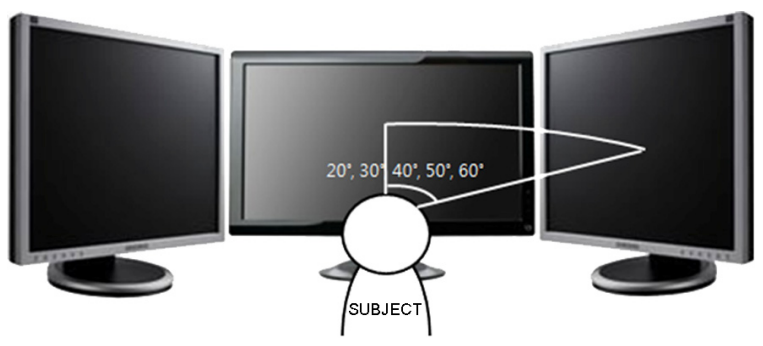

Figure 2. Diagram for experimental setup
두 번째 실험 역시 첫 번째 실험과 같이 Figure 1과 같은 다중 모니터 환경에서 수행하는 것이지만, 두 번째 실험에서 의 한 가지 차이점으로는 피실험자가 찾고자 하는 대상의 위 치를 미리 예측할 수 있도록 하는 것이다. 실험 절차는 아래 와 같다.

1. 실험이 시작하면, 가운데 모니터의 한가운데에 찾아 야 하는 대상의 위치에 대한 힌트가 나타난다. 힌트는 "LEFT-3"과 같은 형태로 나타나며, 첫 번째 글자는 대상이 나타날 위치가 피실험자의 왼쪽 방향인지 오른 쪽 방향인지를 나타내며, 두 번째 글자는 각 방향에 서의 위치를 나타내는 것으로, 1 은 $20^{\circ}, 2$ 는 $30^{\circ}, 3$ 은 $40^{\circ}, 4$ 는 $50^{\circ}, 5$ 는 $60^{\circ}$ 만큼 대상이 떨어져서 나타나 는 것을 뜻한다. 피실험자는 이러한 힌트를 응시하면 서 찾아야 하는 대상이 어느 위치에 나타날 것인지에 대해 예측한다.

2. 3초 후에 힌트가 있던 위치에 "START"라는 글자가 나타나는 동시에 힌트에 따른 위치에 1 3의 숫자가 나타나게 된다. 피실험자는 "START"라는 글자를 확 인한 뒤, 예측했던 위치로 시선을 이동한다.

3. 나타난 숫자에 해당하는 값을 키보드에 입력한다. 이때, "START"가 나타날 때부터 값을 입력할 때까지의 시 간이 저장된다.

4. 각 각도마다 왼쪽 5 번, 오른쪽 5 번 반복하여 수행한다. 또한, 오류가 발생하였을 경우 다시 수행하도록 하였다.

이 두 가지 실험 절차의 차이는 첫 번째 실험에서는 피실 험자가 2번 절차에서 Where System과 What System 모 두를 수행하지만, 두 번째 실험에서는 1 번 절차에서 대상의 위치를 미리 예측함으로써 2 번 절차에서는 What System 만을 수행하도록 한 것이다. 이에 2번 절차의 수행시간을 각각 측정하여 두 실험 결과의 차이로 Where System의 Latency 값을 추출하였다.

\subsubsection{Results}

Figure 3은 첫 번째와 두 번째의 실험 결과로써 두 실험 간의 차이가 분명히 존재함을 알 수 있다. 또한, 두 실험의 수행시간의 평균값들에 대한 차이를 $\mathrm{t}$-검정의 쌍체비교를 통해서 알아본 결과, $p$-value가 0.01 로 유의수준 0.05 상 에서 차이가 존재한다는 것을 알 수 있었다. 이는 앞서 언급 한 바와 같이 넓은 작업 영역에서의 시각 처리 시 Where System에서 시간이 소요된다는 것을 나타낸다. 이에 본 
연구에서는 두 실험 결과의 차이로써 Where System의 Latency 값을 추출하였다.

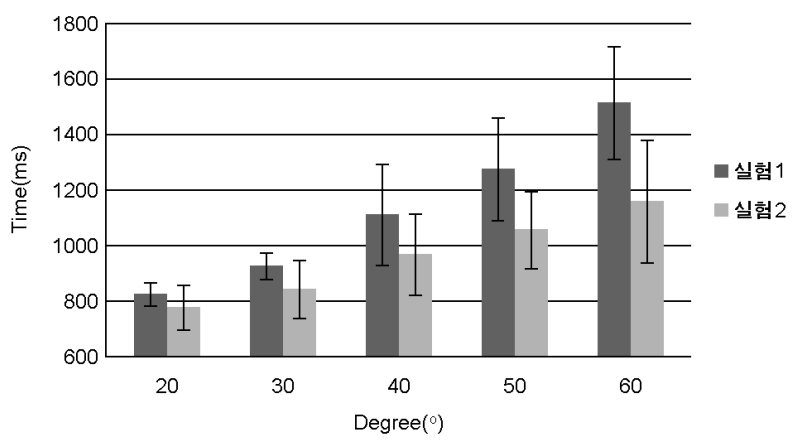

Figure 3. Mean latencies for target offset angles

Figure 4는 두 실험 결과의 차이를 그래프로 나타낸 것으 로써 직선의 형태가 아닌 지수 형태를 나타내고 있기 때문 에 Equation (1)과 같이 지수 형태의 회귀식 $(p-$ value $=$ <.0001)을 구성하였다.

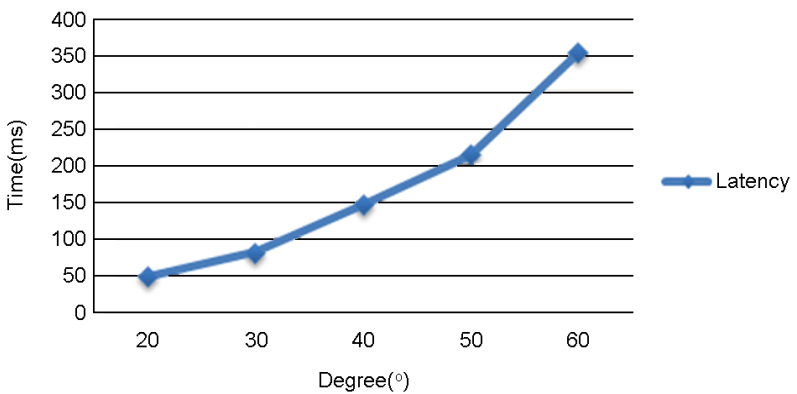

Figure 4. Mean latency differences between experiments 1 and 2 for target offset angles

$$
\text { Latency }=e^{-3.76} \times e^{0.04 \times \operatorname{deg} \text { ree }}
$$

이 식의 단위는 milliseconds이며, degree는 현재 사람 이 응시하고 있는 위치에서 찾고자 하는 대상의 위치 사이 의 각도를 나타낸다. 이 회귀식의 $r^{2}$ 값은 0.99로 Where System에서의 Latency 값을 잘 표현하고 있다는 것을 알 수 있다.

\subsection{Experiment 3}

앞서 진행한 실험들을 통해 얻어진 where system의 latency 값을 이용하여 다중 모니터에서 대상을 찾는 사람 의 수행시간을 예측하는 모델을 작성하고 이 모델이 실제 사 람의 행동을 잘 모의하고 있는지 확인하기 위한 실험을 수 행하였다. 피실험자들과 실험 장비는 앞선 실험과 동일하다.

\subsubsection{Procedures}

모델과 실험에 대한 과제의 수행 절차는 다음과 같다.

1. 가운데 모니터의 한가운데 위치에 1 4 사이의 숫자가 나타난다. 피실험자는 그 숫자를 응시하면서 기억한다.

2. 3초 후에 숫자가 있던 위치에 "START"라는 글자가 나타나는 동시에 모니터 한가운데 위치로부터 오른 쪽으로 $10^{\circ}, 30^{\circ}, 50^{\circ}$ 중 임의의 하나의 각만큼 떨어 진 위치에 1 4의 숫자가 적힌 버튼 4 개가 나타난다. 피실험자는 버튼들이 있는 위치로 시선을 이동한다.

3. 버튼들이 있는 위치로 시선을 이동한 후에 기억하고 있던 숫자가 적힌 버튼을 마우스를 이용하여 누른다. 이때, "START"가 나타날 때부터 마우스를 이용해 값 을 입력할 때까지의 시간이 저장된다.

4. 각 각도마다 5 번 반복하여 수행한다. 또한, 오류가 발 생하였을 경우 다시 수행하도록 하였다.

\subsubsection{Cognitive model}

본 연구의 $\mathrm{ACT}-\mathrm{R}$ 인지 모델은 세 번째 실험과 동일한 과제를 수행하는 모델로서 기존의 $\mathrm{ACT}-\mathrm{R}$ 시각처리 과정 을 그대로 따른다. 더 자세히 살펴보면, 모니터 한가운데 숫 자가 나타나면, 그 숫자를 ACT-R 모델의 Goal Module 안 에 저장한 뒤, 3초 후에 "START" 글자와 버튼들이 나타나 면, "START" 버튼을 인식한 후에 먼저, Where System (Visual Module 안의 Visual-location Buffer)에서 4개의 버튼 중 Goal Module 안에 있는 숫자가 들어있는 버튼의 위 치를 찾는다. 여기서 앞서 실험을 통해 얻어진 Latency 값 이 적용되며, 개인차를 표현하기 위해 0.05 의 표준편차와 계산된 Latency 값을 평균으로 가진 Gaussian 분포를 통한 임의의 값을 Latency 값으로 사용하였다. 이 Gaussian 분 포는 $\mathrm{ACT}-\mathrm{R}$ 모델에서 개인차를 표현할 때 주로 사용되는 분포이다. 버튼의 위치가 확인되면, What System에서 그 위 치로 주의(시선)를 이동시킨다. 주의 이동이 완료되면 마우 스를 이용하여 버튼을 누른다.

모델을 구성하는 Production Rule들은 다음과 같다.

1. Searching-number: 모니터 가운데에 있는 숫자의 위 
치를 탐색.

IF the goal is to find a number

THEN search an unattended letter in the middle of display.

2. Attending-number: 탐색한 위치를 향해 주의를 이동. IF the goal is to attend the number, and there is the visual-location of the number

THEN move visual attention to the location.

3. Encoding-number: 주의를 옮겨 숫자를 확인하여 저장.

IF the goal is to encode a number, and there is visual object in the current location

THEN save the value of the number in the goal buffer.

4. Searching-start-mark: 숫자를 확인한 후, "START" 글자가 나타날 때까지 기다려 위치를 탐색.

IF the goal is to find a start

THEN search an "start" letter in the middle of display.

5. Attending-start-mark: 탐색한 위치를 향해 주의를 이동.

IF the goal is to attend the start, and there is the visual-location of the "start" letter

THEN move visual attention to the location.

6. Encoding-start-mark: 주의를 옮겨 "START" 글자 를 확인하였으면, 저장되어 있는 숫자에 해당되는 버 튼의 위치를 탐색.

IF the goal is to search target button, and there is visual object in the current location

THEN search an unattended letter in the button corresponding to the number in goal buffer.

7. Attending-button: 탐색한 위치를 향해 주의를 이동 하는 동시에 마우스 역시 그 위치로 이동.

IF the goal is to attend the button, and there is the visual-location of the button

THEN move visual attention to the location, and move the mouse to the location.

8. Encoding-button: 주의를 옮겨 버튼을 확인하여 마 우스를 클릭함.

IF the goal is to click mouse, and there is visual object in the current location

THEN click mouse.

이와 같은 8개의 Rule들 중 6번 Rule이 Where System 에 해당하며, 7번과 8번 Rule이 What System이다. 이러한 Rule들로 구성된 인지 모델은 실제 피실험자와 비교를 위해 모델 역시 각 각도마다 5 번 반복하여 과제를 수행하도록 하였다.

\subsubsection{Results}

Figure 5는 ACT-R 인지 모델과 실제 피실험자의 결 과값을 나타낸다. 본 연구에서는 실제 피실험자의 결과와 $\mathrm{ACT}-\mathrm{R}$ 인지 모델의 예측 값을 비교하기 위해서 회귀분석 을 수행하였다. Campbell과 Bolton(2005)에 의하면, 인지 모델과 피실험자와의 결과를 통계적으로 비교하기 위해서는 전통적인 가설 검정 방법은 적합하지 않고 회귀분석을 통한 적합도를 살펴보아야 한다고 주장하고 있다. 이에 본 연구 에서도 실제 피실험자의 결과와 모델의 결과를 비교하기 위 해 회귀분석을 통한 $\mathrm{r}^{2}$ 값과 RMS 값을 계산하였더니, $\mathrm{r}^{2}=$ 0.98, RMS=29.09라는 값이 도출되었다. 이는 본 연구에 서의 인지모델이 실제 사람의 행동을 잘 나타내고 있다는

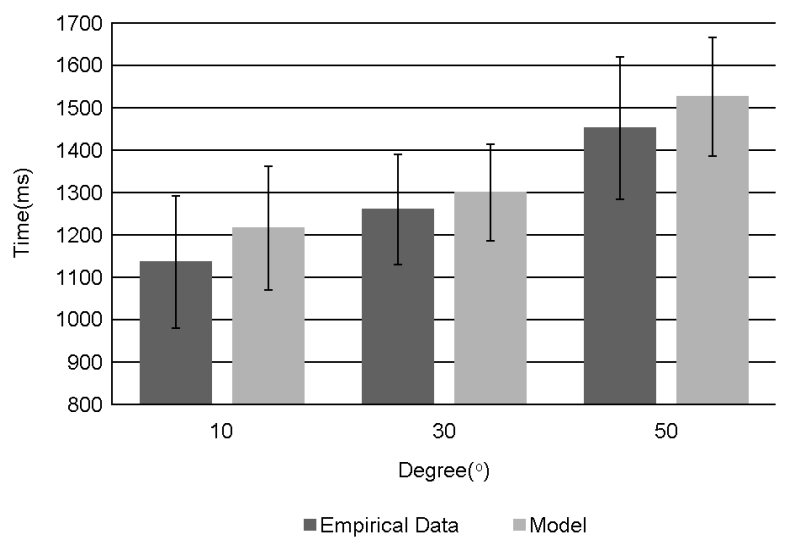

Figure 5. Predicted (ACT-R model) and empirical performance times for target offset angles 
것을 의미한다.

\section{Discussion}

본 연구에서는 다중 모니터 인터페이스에서의 사람의 행 동을 묘사할 수 있는 ACT-R 인지 모델을 개발하였으며, 실험을 통해 검증하였다.

ACT-R Cognitive Architecture는 기존의 많은 연구들 을 통해 모니터 안의 대상을 인식하는 사람의 행동을 묘사 하는 모델을 작성하는 데 적합하다는 것이 입증되어 왔다 (Anderson et al., 1997; Byrne, 2001; Ehret, 2000; Fleetwood \& Byrne, 2002). 하지만, 이는 대부분 하나의 모니터에서만 이루어져 왔기 때문에 다중 모니터와 같이 넓은 작업 영역에서 역시 적합한지에 대해서는 연구가 이 루어지지 않았다. 이에 본 연구에서는 $\mathrm{ACT}-\mathrm{R}$ 의 Where System의 Latency 값을 실험을 통해 추출하여 $\mathrm{ACT}-\mathrm{R}$ 자 체의 기본적인 시각 처리 과정인 Where System과 What System을 그대로 유지하면서도 다중 모니터와 같이 넓은 작업 영역에서의 사람의 행동을 정확하게 표현할 수 있다는 것을 입증하였다. 또한, 넓은 작업 영역에서의 사람의 시각 처리는 보다 큰 개인차를 보이게 되는데 본 연구에서는 이를 Gaussian 분포를 이용하여 비교적 정확하게 예측하고 있다.

이는 다중 모니터 환경에서 역시 본 연구를 바탕으로 $\mathrm{ACT}-\mathrm{R}$ 을 이용한 인지 모델을 작성할 수 있다는 것을 의미 한다. 이에, 새로운 인터페이스 시스템을 개발하는 데 있어 서 본 연구를 바탕으로 $\mathrm{ACT}-\mathrm{R}$ 을 이용한 인지 모델을 작성 하여 Model-based Evaluation을 수행하면 기존의 사용성 평가 방식에 비해 더 빠르고 경제적이며 정량적인 평가를 가 능하게 해 줄 수 있다.

\section{Conclusion}

본 연구에서는 최근 다양한 분야에서 사용되고 있는 다중 모니터에서의 사람의 행동을 묘사할 수 있는 인지 모델을 $\mathrm{ACT}-\mathrm{R}$ Cognitive Architecture을 이용하여 작성하였다. 이러한 인지모델은 실험 결과에서 알 수 있듯이 다중 모니터 와 같은 넓은 작업 영역에서 원하는 대상을 찾는 행동을 실 제 사람과 유사하게 모의하고 있다. 이에 다중 모니터에서의 Model-based Evaluation을 수행하는 데 사용되어 인터페 이스 설계 시 정량적이고 효율적인 평가가 가능하다.

\section{Acknowledgements}

This research was supported by the Converging Research Center Program through the Converging Research Headquarter for Human, Cognition and Environment funded by the Ministry of Education, Science and Technology (No. 2012K001333). This work was also supported by the National Research Foundation of Korea (NRF) grant funded by the Korea government (MEST) (No. 2012047330)

\section{References}

Anderson, J.R., Bothell, D., Byrne, M.D., Douglass, S., Lebiere, C. and Qin, Y., An Integrated Theory of Mind, Psychological Review, 111 1036-1060, 2004.

Anderson, J.R. and Matessa, M., The rational analysis of categorization and the ACT-R architecture. In M. Oaksford \& N. Chater (Eds.) Rational models of cognition, Oxford: Oxford University Press, 197 $-217,1998$.

Anderson, J.R., Matessa, M. and Lebiere, C., ACT-R: A theory of higher level cognition and its relation to visual attention. Human Computer Interaction, 12(4), 439-462, 1997.

Byrne, M.D., ACT-R/PM and Menu Selection: Applying a Cognitive Architecture to HCI, International Journal of Human-Computer Studies, Volume 55, Issue 1, 41-84, 2001.

Byrne, M.D. and Anderson, J.R., Enhancing ACT-R's Perceptual-Motor Abilities. In Proceedings of the Nineteenth Annual Conference of the Cognitive Science Society, Hillsdale, NJ: Lawrence Erlbaum Associates. 1997.

Byrne, M.D. and Anderson, J.R., Perception and action, In J. Anderson and J. Lebiere (Ed), The Atomic Components of Thought, Mahwah, NJ: Lawrence Erlbaum, 167-200, 1998.

Campbell, G.E. and Bolton, A.E., HBR Validation: Integrating Lessons Learned From Multiple Academic Disciplines, Applied Communities, and the AMBR Project. In K. Gluck and R. Pew (Ed), Modeling Human Behavior with Integrated Cognitive Architectures, Hillsdale, NJ: Lawrence Erlbaum Associates, 2005.

Card, S.K., Moran, T.P. and Newell, A., The Psychology of Human Computer Interaction, L. Erlbaum Associates, 1983.

Chung, Y.K., Case Analysis of Multi Display and A Study on Management Interface. Journal of Korea Design Knowledge. 18, 180-189, 2011.

Ehret, B.D., Learning where to look: The acquisition of location knowledge in display-based interaction. Dissertation Abstracts International: Section B: the Sciences \& Engineering, 60(10-B), 5239, 2000.

Fleetwood, M.D. and Byrne, M.D., Modeling icon search in ACT-R/PM. Cognitive Systems Research, 3, 25-33, 2002.

Goodale, M.A. and Milner, A.D., Separate visual Pathways for Perception 
and Action, Trends in Neurosciences, 15(1), 20-25, 1992.

http://act-r.psy.cmu.edu

John, B.E. and Kieras, D.E., Using GOMS for User Interface Design and Evaluation: Which Technique?, ACM Transactions on ComputerHuman Interaction, 3(4), 287-319, 1996a.

John, B.E. and Kieras, D.E., The GOMS Family of User Interface Analysis Techniques: Comparison and Contrast, ACM Transactions on Computer-Human Interaction, 3(4), 320-350, 1996 b.

Kieras, D.E. and Meyer, D.E., An overview of the EPIC architecture for cognition and performance with application to human-computer interaction. Human-Computer Interaction 12, pp. 391-438, 1997.

Laird, J.E., Newell, A. and Rosenbloom, P.S., SOAR: An architecture for general intelligence, Artificial Intelligence, 33, pp. 1-64, 1987.

Lim, S., Jo, S., Myung, R., Kim, S., Jang, E. and Park, B., ACT-R Predictive Model of Korean text Entry on Touchscreen, Journal of the Ergonomics Society of Korea, 31(2), 291-298, 2012.

Min, J., Jo, S. and Myung, R., Prediction of Menu Selection on Touchscreen using a Cognitive Architecture: ACT-R, Journal of the Ergonomics Society of Korea, 29(6), 907-914, 2010.

Salvucci, D.D., Modeling driver behavior in a cognitive architecture. Human Factors, 48, 362-380, 2006.

Sanders, M.S. and McCormick, E.J., Human factors in Engineering and design, 7th Edition. McGraw-Hill Book Company, NY. 1993.

St. Amant, R., Horton, T.E. and Ritter, F.E., Model-Based Evaluation of Expert Cell Phone Menu Interaction. ACM Transactions on ComputerHuman Interaction, Vol. 14, No. 1, Article 1, 2007.

U.S. Department of Defense, Human Factors Engineering Design for Army Material MIL-HDBK 759A, Washington, DC. 1981.
Rohae Myung: rmyung@korea.ac.kr

Highest degree: Ph.D., Industrial Engineering, Texas Tech University Position title: Professor in School of Industrial Management Engineering, Korea University

Areas of interest: HCI, Cognitive Modeling

Sang-Hyeob Kim: shk1028@etri.re.kr

Highest degree: Ph.D., Department of Apply Physics, Tohoku University Position title: Principle Member of Engineering Staff, BT Convergence Technology Research Department, Electronics and Telecommunications Research Institute

Areas of interest: Cognition Convergence, Emotion Recognition

Eun-Hye Jang: cleta4u@ etri.re.kr

Highest degree: Ph.D., Department of Psychology, Chungnam National University

Position title: Researcher, BT Convergence Technology Research Department, Electronics and Telecommunications Research Institute Areas of interest: Cognition Convergence, Emotion Recognition

Byoung-Jun Park: bj_park@etri.re.kr

Highest degree: Ph.D., Department of Electrical Engineering, Wonkwang University

Position title: Senior Member of Engineering Staff, BT Convergence Technology Research Department, Electronics and Telecommunications Research Institute

Areas of interest: Computational Intelligence, Pattern Recognition

Date Received : 2012-05-14

Date Revised :2013-03-20

Date Accepted : 2013-03-20

\section{Author listings}

Hyungseok Oh: prohyung@korea.ac.kr

Highest degree: M.E., Industrial Management Engineering, Korea

University

Areas of interest: HCI, Cognitive Modeling 